\title{
DISTRIBUTION OF CATFISHES IN WETLANDS OF TWO FLOOD PLAIN DISTRICTS IN TAMIL NADU, INDIA
}

\section{B. Rajagopal ${ }^{1} \&$ Priya Davidar $^{2}$}

${ }^{1}$ Department of Biotechnology, Malankara Catholic College, Mariagiri, Kaliakkavilai, Tamil Nadu 629153, India ${ }^{2}$ Department of Ecology and Environmental Sciences, School of Life Sciences, Pondicherry University, Kalapet, Puducherry 625014, India

${ }^{1}$ mathanagopalb@yahoo.com (corresponding author), ${ }^{2}$ pdavidar@yahoo.com

\section{OPEN ACCESS}

Abstract: A study was conducted on the distribution of catfishes in selected wetlands in Kancheepuram and Kanyakumari districts of Tamil Nadu, southern India. Different types of wetlands such as tanks, pools, lakes, open wells and estuaries were selected for the study based on their different environmental set up. Fishes were collected with the help of fishermen using cast and seine nets. Twelve species of catfishes from five families (Ariidae, Bagridae, Heteropneustidae, Schilbeidae and Siluridae) were recorded, of which 10 species from four families were from Kanyakumari and six species belonging to three families were from Kancheepuram District. In Kancheepuram, the species recorded were Heteropneustes fossilis, Mystus seengtee, M. gulio, M. keletius, M. vittatus and Neotropius atherinoides, and in Kanyakumari the species recorded were Arius arius, Arius subrostratus, Heteropneustes fossilis, Mystus armatus, M. seengtee, M. gulio, M. montanus, $M$. vittatus, Ompok bimaculatus and O. malabaricus. Among the wetlands, the highest species richness was seen in Puthery and Erachakulam tanks in Kanyakumari and Chembarampakkam Lake in Kancheepuram. The lowest species richness was observed was in Vishnupuram, Thotiode tanks and Mavadi pool of the former district and Vandalur Tank, Kalpakkam Estuary of the latter. Environmenta factors such as microhabitat diversity and substrate diversity in the wetlands significantly influenced species richness.

Keywords: Catfish, distribution, environmental factors, Kancheepuram, Kanyakumari, species richness, Tamil Nadu.
Catfish, which is a significant group of the fishes in wetlands, are economically important with a high nutrient value. About 197 species of catfishes from 52 genera are found in India. The Indian families include Bagridae, Siluridae, Schilbeidae, Pangasiidae, Amblycipitidae, Sisoridae, Clariidae, Heteropneustidae, Chacidae, Olyridae, Akysidae, Ariidae and Plotosidae (Jayaram 2006).

Catfishes dwell in diverse habitats such as upland streams, large river channels and seasonal floodplain lagoons (Winemiller \& Winemiller 1996). Although, there are many studies conducted on the systematics, feeding, breeding ecology and morphometrics of fishes in India, studies on their distribution including species richness, abundance and composition are limited (Kumar \& Mittal 1993; Kumar et al. 1995, 1999).

The freshwater catfishes of Tamil Nadu are mainly of the genera Glyptothorax, Sperata, Neotropius, Mystus, Heteropneustes, Ompok, Clarias and Wallago. The estuarine catfishes of the region are from the genera Arius and Mystus.

Raj (1916) recorded eight species, and more recently, Venkateswarlu et al. (1975) recorded 18 species from six families from Kancheepuram and its adjacent districts.

DOI: http://dx.doi.org/10.11609/JoTT.o2889.5277-82 | ZooBank: urn:Isid:zoobank.org:pub:EB13F819-9183-41AC-98ED-AD3B71D2F14A

Citation: Rajagopal, B. \& P. Davidar (2013). Distribution of catfishes in wetlands of two flood plain districts in Tamil Nadu, India. Journal of Threatened Taxa 5(17): 5277-5282; http://dx.doi.org/10.11609/JoTT.02889.5277-82

Copyright: (C Rajagopal \& Davidar 2013. Creative Commons Attribution 3.0 Unported License. JoTT allows unrestricted use of this article in any medium, reproduction and distribution by providing adequate credit to the authors and the source of publication.

Funding: None.

Competing Interest: None.

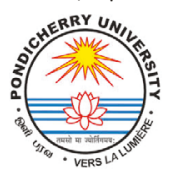

Acknowledgements: We express our sincere thanks to Dr. R.J. Ranjit Daniels, Director, Care Earth Chennai and Dr. Robert B. Grubh, Director, Institute for Restoration of Natural Environment, Nagercoil for giving us permission to use their laboratory and other supports. We also thank Dr. Rema Devi, Senior Scientist, Zoological Survey of India, Chennai who helped us in specimen identification and Dr. Mark Henry Sabaj, Collection Manager, All Catfish Species Inventory, U.S.A for sending literature on catfish ecology. We would also like to extend our gratitude to the anonymous reviewers of this manuscript for helping us to improve upon its quality. This study was a part of the PhD research of the first author at Department of Ecology \& Environmental Sciences, Pondicherry University, Puducherry, India. 
Chembarampakkam Lake is an important water body for catfishes in Kancheepuram. Raghunathan (1978) listed six species from three families; Daniels \& Rajagopal (2004) recorded four species from two families in this lake.

The catfish records from Kanyakumari District of Tamil Nadu include that of Singh (1976), who has listed 11 species of catfish, of which four were marine and seven were freshwater species. Indra (1992) recorded five species of catfishes from Kanyakumari. Among these, four species belong to the genus Mystus and one belongs to the genus Heteropneustes of the families Bagridae and Heteropneustidae respectively. The present study was conducted in the two regions of southern India in order to: (1) survey the distribution and species richness of catfishes in wetlands of these regions and (2) identify the factors influencing their distribution.

\section{Methods}

Study Area: The study regions were located in Kancheepuram and Kanyakumari Districts of Tamil Nadu State, southern India. The study regions were selected based on the difference in geography, climate and catfish species composition. Kancheepuram District is located on the northeastern coast of Tamil Nadu, closer to the Eastern Ghats, covering $440 \mathrm{~km}^{2}$ area, approximately between $12^{\circ} 30^{\prime}-13^{\circ} 10^{\prime} \mathrm{N} \& 79^{\circ} 40^{\prime}-80^{\circ} 20^{\prime} \mathrm{E}$ (Fig. 1). Kanyakumari is located on the southern most end of the Indian peninsula near the Western Ghats at about $8^{0} 03^{\prime}-8^{0} 35^{\prime} \mathrm{N} \& 77^{\circ} 15^{\prime}$ $77^{0} 36^{\prime}$ E. Kanyakumari district has an area of $167 \mathrm{~km}^{2}$ (Fig. 2).

For the present study, 25 wetlands were studied, of which, 10 were located in Kancheepuram and 15 were located in Kanyakumari (Figs. 1 \& 2).

The wetlands of Kancheepuram District obtain water from the River Palar and its tributaries such as Cheyyar and Vegavathy. Palar originates from the 'Western Ghats' in Karnataka State and finally empties into the Bay of Bengal.

Five main rivers such as Tamiraparani, Pazhayar, Valliar, Ponniavaikal, Paralayar and their tributaries fill the ponds and lakes of Kanyakumari District. The major river of the district, Tamiraparani originates from the Western Ghats and has two main tributaries viz., Kodayar and Paralayar. The river empties into the Arabian Sea at Thenkapatnam. Among the other rivers, Valliar originates in Velimalai Hills and joins the Arabian Sea near Manavalakurichi while river Pazhayar originates from Shorlacode and joins the Arabian Sea near Manakudy.

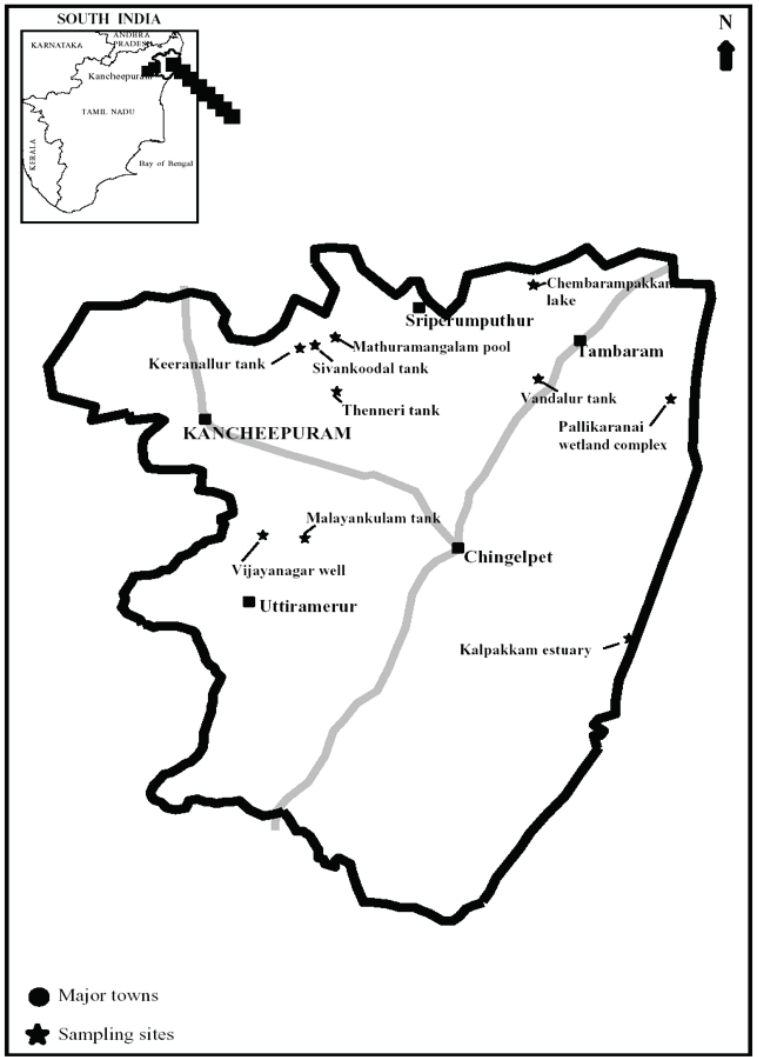

Figure 1. Map showing the study sites in Kancheepuram District $\left(79^{\circ} 40^{\prime}-80^{\circ} 20^{\prime} \mathrm{E} \& 12^{\circ} 30^{\prime}-13^{\circ} 10^{\prime} \mathrm{N}\right)$

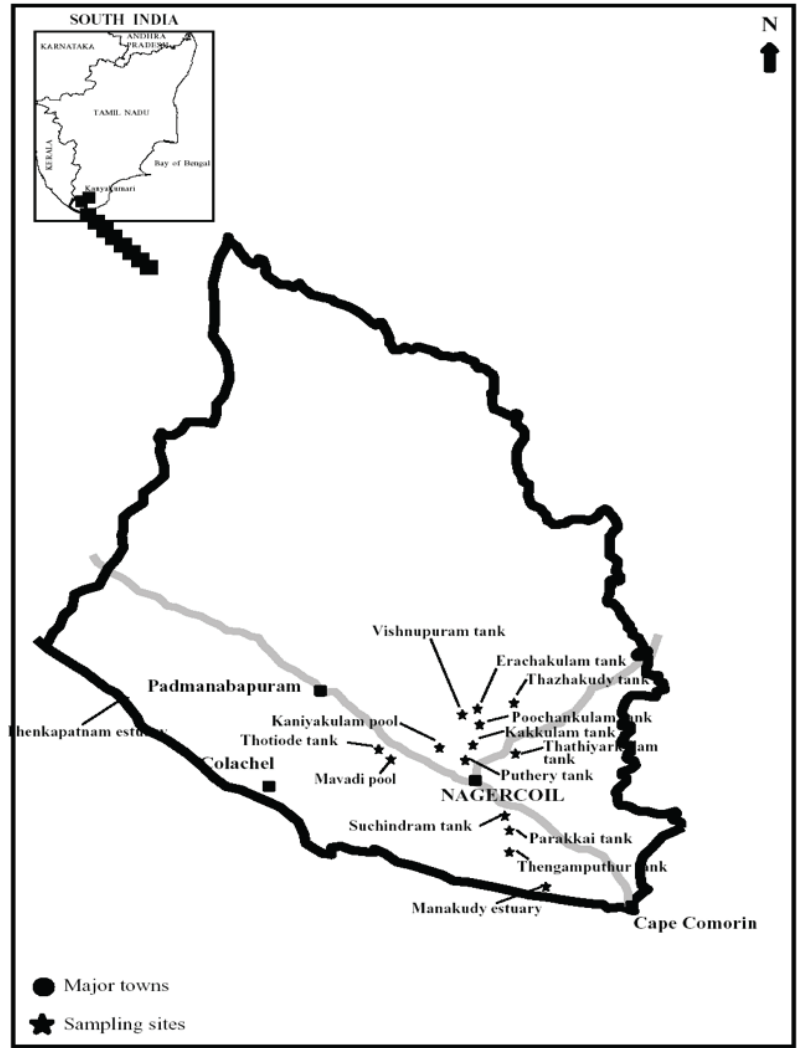

Figure 2. Map showing the study sites in Kanyakumari District $\left(77^{0} 15^{\prime}-77^{0} 36^{\prime} \mathrm{E} \& 8^{0} 03^{\prime}-8^{0} 35^{\prime} \mathrm{N}\right)$. 
Different types of wetlands such as tanks, pools, lake, open wells and estuaries were selected for the study based on the nature of their surface and substrate (open/closed with vegetation), seasonality (seasonal/perennial) and size (Large, Medium, Small) based on the findings that different cat fish species prefers diverse habitats (Kumar \& Mittal 1993).

Among the 25 wetlands studied, 21 of them were fresh water and four were brackish water. The different wetland types and their distribution in the two study regions along with their environmental factors have been provided in Table 2 and Fig. 3.

Fish sampling: Fish sampling was carried out from February2003 to April2004 in the wetlands of Kancheepuram and Kanyakumari districts in different seasons. However, sampling was mostly concentrated during the summer, considering the low water level in wetlands and bottom dwelling habit of the catfish. Moreover, the wetlands were sampled at different sites so that a representative section of all habitats could be covered and the sampling effort was higher in the larger wetlands. In addition, sampling was also done during the peak summer when the level of water was less. Hence, all catfish species of a wetland were sampled and the chance of escape of any species during sampling was avoided.

Fishes were collected with the help of fishermen using

Table 1. Distribution of fish species and their relative abundance in two districts

\begin{tabular}{|c|c|c|c|}
\hline \multirow[t]{2}{*}{ Family } & \multirow[t]{2}{*}{ Species } & \multicolumn{2}{|c|}{ Relative abundance (\%) } \\
\hline & & $\begin{array}{l}\mathrm{KP} \text { (Total } \\
\mathrm{N}=753 \text { ) }\end{array}$ & $\begin{array}{l}\mathrm{KK} \text { (Total } \\
\mathrm{N}=811)\end{array}$ \\
\hline \multirow[t]{2}{*}{ Ariidae } & $\begin{array}{l}\text { Arius arius (Hamilton, } \\
\text { 1822) }\end{array}$ & 0 & 9.80 \\
\hline & $\begin{array}{l}\text { Arius subrostratus } \\
\text { Valenciennes, } 1840\end{array}$ & 0 & 1 \\
\hline \multirow{6}{*}{ Bagride } & $\begin{array}{l}\text { Mystus armatus (Day, } \\
1865 \text { ) }\end{array}$ & 0 & 29 \\
\hline & $\begin{array}{l}\text { Mystus gulio (Hamilton, } \\
\text { 1822) }\end{array}$ & 13.80 & 11.40 \\
\hline & $\begin{array}{l}\text { Mystus keletius } \\
\text { (Valenciennes, 1840) }\end{array}$ & 0.13 & 0 \\
\hline & $\begin{array}{l}\text { Mystus montanus (Jerdon, } \\
1849 \text { ) }\end{array}$ & 0 & 4.90 \\
\hline & $\begin{array}{l}\text { Mystus seengtee (Sykes, } \\
1839 \text { ) }\end{array}$ & 0.53 & 0.12 \\
\hline & $\begin{array}{l}\text { Mystus vittatus (Bloch, } \\
\text { 1794) }\end{array}$ & 43.20 & 23.90 \\
\hline Heteropneustidae & $\begin{array}{l}\text { Heteropneustes fossilis } \\
\text { (Bloch, 1794) }\end{array}$ & 28.50 & 15.80 \\
\hline Schilbeidae & $\begin{array}{l}\text { Neotropius atherinoides } \\
\text { (Bloch, 1794) }\end{array}$ & 13.80 & 0 \\
\hline \multirow[t]{2}{*}{ Siluridae } & $\begin{array}{l}\text { Ompok bimaculatus } \\
\text { (Bloch, 1794) }\end{array}$ & 0 & 0.37 \\
\hline & $\begin{array}{l}\text { Ompok malabaricus } \\
\text { (Valenciennes, 1840) }\end{array}$ & 0 & 3.30 \\
\hline
\end{tabular}

KP - Kancheepuram; KK - Kanyakumar cast and seine nets. Seines were used for tanks and pools with shallow $(<2 \mathrm{~m})$ waters and the cast net was used for tanks, lake and estuaries with deep waters $(>2 \mathrm{~m})$. The selection of nets was also based on the fact that different species of catfish inhabits various habitats such as open water, closed water with vegetation and sluice in the wetlands as recorded by Kumar et al. (1995), Zacharias et al. (1996) and Kumar et al. (1999). The cast net used was of $4 \mathrm{~m}$ radius with $0.005 \mathrm{~m}$ mesh. Two types of seines were used, one was of $70 \mathrm{~m}$ long and $6 \mathrm{~m}$ wide with $0.01 \mathrm{~m}$ mesh, and the other one was of $5 \mathrm{~m}$ long, $2 \mathrm{~m}$ wide with $0.003 \mathrm{~m}$ mesh.

The fish sampling effort for cast net depended upon the size (small/medium/large) of the studied wetland. As the sampling area covered in this net was comparatively smaller, three/five/ten samples were done according to the size of the respective wetland.

Two samples for large seine and five samples for small seine nets were maintained. However, the number of catch effort varied for the cast net, uniform effort was maintained for the seines that covered the major sampling area. The duration of sampling effort for large seine was on an average of 5 hours/seine/day and for small seine it was 30 minutes /seine/day.

Identification and preservation: Fishes collected from different wetlands were labelled and preserved in $10 \%$ formalin solution. They were identified in the laboratory using the standard taxonomic keys (Talwar \& Jhingran 1991; Jayaram 1999).

Habitat characterization: Each wetland was surveyed and the biotic and abiotic parameters were recorded to find out their influence on fish species richness. The biotic factors were vegetation strata, vegetation diversity of the wetlands and abiotic factors were wetland area, substrate type (sandy/muddy/rocky), microhabitat (the temporary, permanent pools, sluices and channels), depth (High, low, medium) and type of water.

The vegetation was classified into three categories including emergent, floating and submerged. The wetland

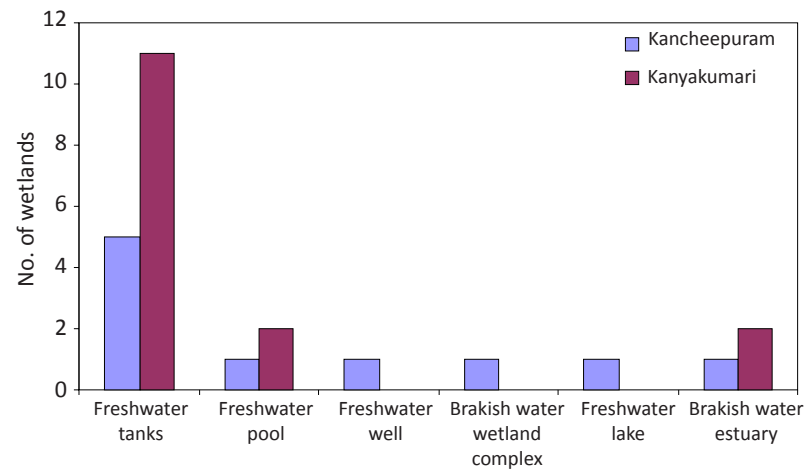

Figure 3. Types of wetlands in both districts. 
vegetation was identified using the wetland vegetation key of the Botanical Survey of India (BSI), Calcutta (Subramanyam 1961). The nature of the substratum (sand/mud/rock) was checked by visual observation. The different microhabitats of the wetlands including the temporary, permanent pools, sluices and channels were noted during the summer when the wetland had little water. The approximate length and breadth of the water body were recorded in meters and then the area of the wetland was calculated to hectares. The list of environmental parameters recorded are given in Table 2.

Statistical analysis: Species diversity (Margalef species diversity index) was calculated using online biodiversity calculator <http://www2.plymouth.ac.uk/science/south_ africa/Docs/Field_course_calc.xlsx>. The relationship between species richness and the wetland characteristics such as area, substrate, depth, biotic and abiotic factors were analyzed by multiple regression analysis using Minitab 15 trial version.

\section{Results}

Species distribution: Twelve species representing five families (Ariidae, Bagridae, Heteropneustidae, Schilbeidae and Siluridae) were recorded in this study. In Kanyakumari, ten species from four families and in Kancheepuram six species from three families were recorded. Catfish of the family Siluridae was not found in Kancheepuram and Schilbeidae was not found in Kanyakumari District respectively (Table 1 ).

Mystus gulio and Mystus vittatus were found in both fresh and brackish waters. Arius arius and Arius subrostratus were found only in brackish water and the other species were seen only in freshwater wetlands.

The highest number of species was seen in Puthery tank (six species), Erachakulam Tank (five species) of Kanyakumari and Chembarampakkam Lake (five species) in Kancheepuram. The lowest number of species was observed in Vishnupuram Tank (one species), Thotiode Tank (one species), and Mavadi Pool (one species) of the former District and Vandalur Tank (one species), Kalpakkam Estuary (one species) of the latter district (Table 2).

Species diversity (Margalef index): Species diversity was more in Chembarampakkam Lake (0.985) in Kancheepuram and Thathiyarkulam Tank (0.971), Puthery Tank (0.967) in Kanyakumari. Diversity was less in Sivankoodal (0.206), in Kancheepuram and Kaniyakulam (0.213) in Kanyakumari, respectively (Table 2 ).

$\%$ Relative abundance: The $\%$ relative abundance was more for species such as Mystus vittatus, Heteropneustes fossilis, Neotropius atherinoides, Mystus gulio and the abundance was less for species such as Mystus seengtee and Mystus keletius in Kancheepuram. The \% relative abundance was more for species such as Mystus armatus, Mystus vittatus, Heteropneustes fossilis, Mystus gulio and the abundance was less for species such as Ompok bimaculatus and Mystus seengtee in Kanyakumari, respectively (Table 1).

Factors influencing species richness: Among various environmental factors tested against species richness, only vegetation diversity and vegetation strata correlated significantly with species richness (Table 3).

\section{Discussion}

Mystus vittatus and Heteropneustes fossilis are widely distributed geographically, whereas Arius subrostratus and Mystus keletius have a restricted distribution. The reason can be attributed to their ecological competence and adaptation to various habitats. Although Mystus gulio was commonly seen in many wetlands, their distribution seems to be restricted to the brackish water wetlands such as Manakudy, Thenkapatnam, Suchindram, Parakkai, Thengamputhur wetlands in Kanyakumari and Pallikaranai, Kalpakkam wetlands of Kancheepuram. All these are located within approximately $10 \mathrm{~km}$ from the sea. These findings suggest that this species prefers to live in wetlands that are located in proximity to the estuary which support their easy migration between the estuary and fresh water wetlands.

The previous catfish surveys in Kanyakumari District (Singh 1976; Indra 1992) have listed about 16 species of catfish from marine and freshwaters. Among these, four were from the marine water, 11 from freshwater and one from brackish water.

Among the eight freshwater catfishes recorded by Singh (1976), Sperata aor, Mystus cavasius, Ompok bimaculatus, Ompok malabaricus, Wallago attu and Clarias dussumieri were not recorded by Indra (1992). Some of the fishes that were recorded such as Mystus armatus, Mystus montanus and Mystus oculatus by Indra (1992) were not done earlier.

During the present study in Kanyakumari, Sperata aor, Wallago attu, Clarias dussumieri, Mystus oculatus, Arius dussumieri and Arius sagor which were already recorded in the previous two surveys (Singh 1976; Indra 1992) were not seen. The marine catfish Arius subrostratus is reported for the first time in this region from Thengapatnam Estuary. Although Talwar \& Jhingran (1991) and Jayaram (1999) have reported its distribution in general in Kerala and Tamil Nadu States, their occurrence in the study site have not been specifically reported.

In Kancheepuram, species such as Wallago attu, Mystus bleekeri and Clarias cf. batrachus recorded by (Raj 1916; Venkateswarlu et al. 1975; Raghunathan 1978; Devi 1998) were not found in this survey. 
Table 2. Number of species, species diversity, biotic and abiotic parameters in wetlands of Kancheepuram and Kanyakumari districts.

\begin{tabular}{|c|c|c|c|c|c|c|c|c|c|}
\hline Name of the Site & $\begin{array}{l}\text { No. of } \\
\text { species }\end{array}$ & $\begin{array}{l}\text { Margalef } \\
\text { index }\end{array}$ & Water type & Area (ha) & $\begin{array}{l}\text { Substrate } \\
\text { diversity }\end{array}$ & $\begin{array}{l}\text { Depth } \\
\text { category }\end{array}$ & $\begin{array}{c}\text { Micro } \\
\text { habitat } \\
\text { diversity }\end{array}$ & $\begin{array}{l}\text { Vegetation } \\
\text { strata }\end{array}$ & $\begin{array}{c}\text { Vegeta } \\
\text { tion } \\
\text { diversity }\end{array}$ \\
\hline \multicolumn{10}{|c|}{ Kancheepuram $\left(12^{\circ} 30^{\prime}-13^{\circ} 5^{\prime} \mathrm{N} \& 79^{\circ} 45^{\prime}-80^{\circ} 15^{\prime} \mathrm{E}\right)$} \\
\hline $\begin{array}{l}\text { Chembarampakkam } \\
\left(12^{\circ} 55^{\prime}-13^{\circ} 5^{\prime} \mathrm{N} \& 80^{\circ} 0^{\prime}-80^{\circ} 5^{\prime} \mathrm{E}\right)\end{array}$ & 5 & 0.985 & FW & 35700 & 4 & 2 & 6 & 3 & 9 \\
\hline $\begin{array}{l}\text { Kalpakkam } \\
\left(12^{\circ} 30^{\prime}-12^{\circ} 35^{\prime} \mathrm{N} \& 80^{\circ} 10^{\prime}-80^{\circ} 15^{\prime} \mathrm{E}\right)\end{array}$ & 1 & 0 & BW & 30 & 2 & 3 & 1 & 0 & 0 \\
\hline $\begin{array}{l}\text { Keeranallur } \\
\left(12^{\circ} 55^{\prime}-13^{\circ} 0^{\prime} \mathrm{N} \& 79^{\circ} 45^{\prime}-79^{\circ} 50^{\prime} \mathrm{E}\right)\end{array}$ & 2 & 0.213 & FW & 75 & 1 & 1 & 1 & 3 & 7 \\
\hline $\begin{array}{l}\text { Malayankulam } \\
\left(12^{\circ} 40^{\prime}-12^{\circ} 45^{\prime} \mathrm{N} \& 79^{\circ} 50^{\prime}-79^{\circ} 55^{\prime} \mathrm{E}\right)\end{array}$ & 2 & 0.402 & FW & 250 & 1 & 1 & 1 & 2 & 5 \\
\hline $\begin{array}{l}\text { Mathuramangalam } \\
\left(12^{\circ} 55^{\prime}-13^{\circ} 0^{\prime} \mathrm{N} \& 79^{\circ} 45^{\prime}-79^{\circ} 50^{\prime} \mathrm{E}\right)\end{array}$ & 2 & 0.514 & FW & 0.1 & 1 & 1 & 1 & 2 & 2 \\
\hline $\begin{array}{l}\text { Pallikaranai } \\
\left(12^{\circ} 55^{\prime}-13^{\circ} 0^{\prime} \mathrm{N} \& 80^{\circ} 10^{\prime}-80^{\circ} 15^{\prime} \mathrm{E}\right)\end{array}$ & 2 & 0.221 & BW & 594 & 4 & 2 & 5 & 3 & 5 \\
\hline $\begin{array}{l}\text { Sivankoodal } \\
\left(12^{\circ} 55^{\prime} 13^{\circ} 0^{\prime} \mathrm{N} \& 79^{\circ} 45^{\prime}-79^{\circ} 50^{\prime} \mathrm{E}\right)\end{array}$ & 2 & 0.206 & FW & 100 & 1 & 1 & 1 & 1 & 3 \\
\hline $\begin{array}{l}\text { Thenneri } \\
\left(12^{\circ} 50^{\prime}-12^{\circ} 55^{\prime} \mathrm{N} \& 79^{0} 50^{\prime}-79^{\circ} 55^{\prime} \mathrm{E}\right)\end{array}$ & 3 & 0.393 & FW & 800 & 3 & 1 & 1 & 2 & 4 \\
\hline $\begin{array}{l}\text { Vandalur } \\
\left(12^{\circ} 50^{\prime}-12^{\circ} 55^{\prime} \mathrm{N} \& 80^{\circ} 0^{\prime}-80^{\circ} 5^{\prime} \mathrm{E}\right)\end{array}$ & 1 & 0 & FW & 75 & 1 & 1 & 4 & 3 & 6 \\
\hline $\begin{array}{l}\text { Vijayanagar } \\
\left(12^{\circ} 40^{\prime}-12^{\circ} 45^{\prime} \mathrm{N} \& 79^{\circ} 45^{\prime}-79^{\circ} 50^{\prime} \mathrm{E}\right)\end{array}$ & 2 & 0.219 & FW & 0.025 & 2 & 1 & 1 & 0 & 0 \\
\hline \multicolumn{10}{|c|}{ Kanyakumari $\left(8^{\circ} 05^{\prime}-8^{\circ} 15^{\prime} \mathrm{N} \& 77^{\circ} 15^{\prime}-77^{\circ} 30^{\prime} \mathrm{E}\right)$} \\
\hline $\begin{array}{l}\text { Erachakulam } \\
\left(8^{0} 10^{\prime}-8^{\circ} 15^{\prime} \mathrm{N} \& 77^{0} 25^{\prime}-77^{0} 30^{\prime} \mathrm{E}\right)\end{array}$ & 5 & 0.813 & FW & 100 & 3 & 2 & 5 & 3 & 14 \\
\hline $\begin{array}{l}\text { Kakkulam } \\
\left(8^{0} 10^{\prime}-8^{0} 15^{\prime} \mathrm{N} \& 77^{0} 25^{\prime}-77^{0} 30^{\prime} \mathrm{E}\right)\end{array}$ & 3 & 0.519 & FW & 0.84 & 2 & 2 & 3 & 3 & 9 \\
\hline $\begin{array}{l}\text { Kaniyakulam } \\
\left(8^{0} 10-8^{0} 15^{\prime} \mathrm{N} \& 77^{\circ} 20-77^{0} 25^{\prime} \mathrm{E}\right)\end{array}$ & 2 & 0.213 & FW & 0.06 & 1 & 1 & 1 & 0 & 0 \\
\hline $\begin{array}{l}\text { Manakudy } \\
\left(8^{\circ} 5^{\prime}-8^{0} 10^{\prime} \mathrm{N} \& 77^{\circ} 25^{\prime}-77^{0} 30^{\prime} \mathrm{E}\right)\end{array}$ & 2 & 0.476 & BW & 30 & 3 & 3 & 1 & 0 & 0 \\
\hline $\begin{array}{l}\text { Mavadi } \\
\left(8^{\circ} 10-8^{\circ} 15^{\prime} \mathrm{N} \& 77^{\circ} 20-77^{\circ} 25^{\prime} \mathrm{E}\right)\end{array}$ & 1 & 0 & FW & 0.5 & 2 & 1 & 1 & 3 & 7 \\
\hline $\begin{array}{l}\text { Parakkai } \\
\left(8^{0} 5^{\prime}-8^{\circ} 10^{\prime} \mathrm{N} \& 77^{\circ} 25^{\prime}-77^{0} 30^{\prime} \mathrm{E}\right)\end{array}$ & 4 & 0.668 & FW & 200 & 1 & 3 & 3 & 3 & 8 \\
\hline $\begin{array}{l}\text { Poochankulam } \\
\left(8^{\circ} 10^{\prime}-8^{\circ} 15^{\prime} \mathrm{N} \& 77^{\circ} 25^{\prime}-77^{\circ} 30^{\prime} \mathrm{E}\right)\end{array}$ & 4 & 0.749 & FW & 0.6 & 2 & 1 & 3 & 2 & 8 \\
\hline $\begin{array}{l}\text { Puthery } \\
\left(8^{0} 10^{\prime}-8^{0} 15^{\prime} \mathrm{N} \& 77^{0} 25^{\prime}-77^{0} 30^{\prime} \mathrm{E}\right)\end{array}$ & 6 & 0.967 & $\mathrm{FW}$ & 300 & 4 & 2 & 6 & 3 & 7 \\
\hline $\begin{array}{l}\text { Suchindram } \\
\left(8^{0} 5^{\prime}-8^{0} 10^{\prime} \mathrm{N} \& 77^{\circ} 25^{\prime}-77^{0} 30^{\prime} \mathrm{E}\right)\end{array}$ & 2 & 0.621 & $\mathrm{FW}$ & 50 & 1 & 2 & 4 & 3 & 6 \\
\hline $\begin{array}{l}\text { Thathiyarkulam } \\
\left(8^{0} 10-8^{0} 15^{\prime} \mathrm{N} \& 77^{\circ} 25^{\prime}-77^{0} 30^{\prime} \mathrm{E}\right)\end{array}$ & 4 & 0.971 & $\mathrm{FW}$ & 38 & 2 & 2 & 4 & 3 & 7 \\
\hline $\begin{array}{l}\text { Thazhakudy } \\
\left(8^{\circ} 10^{\prime}-8^{\circ} 15^{\prime} \mathrm{N} \& 77^{\circ} 25^{\prime}-77^{\circ} 30^{\prime} \mathrm{E}\right)\end{array}$ & 2 & 0.379 & FW & 100 & 1 & 3 & 4 & 0 & 0 \\
\hline $\begin{array}{l}\text { Thengamputhur } \\
\left(8^{\circ} 5^{\prime}-8^{\circ} 10^{\prime} \mathrm{N} \& 77^{0} 25^{\prime}-77^{0} 30^{\prime} \mathrm{E}\right)\end{array}$ & 4 & 0.891 & $\mathrm{FW}$ & 250 & 3 & 1 & 3 & 0 & 0 \\
\hline $\begin{array}{l}\text { Thenkapatnam } \\
\left(8^{\circ} 10^{\prime}-8^{\circ} 15^{\prime} \mathrm{N} \& 77^{\circ} 10^{\prime}-77^{\circ} 15^{\prime} \mathrm{E}\right)\end{array}$ & 3 & 0.504 & BW & 60 & 2 & 3 & 1 & 0 & 0 \\
\hline $\begin{array}{l}\text { Thotiode } \\
\left(8^{\circ} 10-8^{\circ} 15^{\prime} \mathrm{N} \& 77^{0} 20^{\prime}-77^{\circ} 25^{\prime} \mathrm{E}\right)\end{array}$ & 1 & 0 & FW & 4 & 3 & 2 & 1 & 3 & 3 \\
\hline $\begin{array}{l}\text { Vishnupuram } \\
\left(8^{0} 10^{\prime}-8^{0} 15^{\prime} \mathrm{N} \& 77^{0} 25^{\prime}-77^{0} 30^{\prime} \mathrm{E}\right)\end{array}$ & 1 & 0 & $\mathrm{FW}$ & 25 & 2 & 2 & 4 & 2 & 5 \\
\hline
\end{tabular}

BW - Brackish water; FW - Fresh water; KK - Kanyakumari; KP - Kancheepuram;

Mystus oculatus in Kanyakumari and Mystus bleekeri in Kancheepuram were not recorded during the present study, probably because the sampling was restricted only to the lentic fresh water wetlands (wells, pools, tanks and lake) and estuaries. Whereas, Indra (1992) in Kanyakumari and others in Kancheepuram have sampled various freshwater bodies such as rivers, streams and paddy fields. Wallago attu, Clarias dussumieri in Kanyakumari and Wallago attu, 
Table 3. Regression analysis of relationship between number of species and independent variables.

\begin{tabular}{|l|c|c|c|c|}
\hline \multicolumn{1}{|c|}{ Predictor } & Coef & SE Coef & T & P \\
\hline Constant & 1.2533 & 0.7565 & 1.66 & 0.115 \\
\hline Area & 0.00000900 & 0.00003519 & 0.26 & 0.801 \\
\hline Substrate diversity & 0.4014 & 0.2484 & 1.62 & 0.124 \\
\hline Depth category & -0.0805 & 0.3074 & -0.26 & 0.796 \\
\hline $\begin{array}{l}\text { Microhabitat } \\
\text { diversity }\end{array}$ & 0.2359 & 0.1766 & 1.34 & 0.198 \\
\hline Vegetation strata & -0.6982 & 0.3190 & -2.19 & $0.042^{*}$ \\
\hline Vegetation diversity & 0.2977 & 0.1172 & 2.54 & $0.020^{*}$ \\
\hline
\end{tabular}

$* \mathrm{P}<0.05$

Clarias cf. batrachus in Kancheepuram might be very rare as people tend to overexploit them for food as these fish are large in size.

The presence of Sperata aor in this region (Kanyakumari) is doubtful as it is distributed from northern India down to the Krishna River system of Andhra Pradesh in the south (Talwar \& Jhingran 1991). No other survey has reported this species from the study region. Arius subrostratus might have been misidentified as Sperata aor as this also has a spatula shaped head like the former. The marine species such as Arius dussumieri and Arius sagor were not recorded as they are primarily marine and might be seasonal migrants to the estuary.

The wetlands such as Puthery (six species), Erachakulam (five species) and Chembarampakkam (five species) are species rich. The Margalef species diversity index is also more for Puthery in Kanyakumari and Chembarampakkam in Kancheepuram.

The statistical analysis proves that the species richness is related to the environmental factors such as vegetation diversity and vegetation strata.

Many authors have studied the influence of various environmental factors on fish species richness. Studies on the influence of environmental factors on fish species richness showed that the water temperature, total alkalinity, TDS and conductivity were highly correlated with this (Johal et al. 2001). Bhat (2004) found that the stream depth and altitude determines the species richness in the streams of central Western Ghats, India.

Angermeier \& Schlosser (1989) found that the species richness was strongly correlated with habitat complexity and site volume of wetlands in Panama. Amarasinghe \& Welcomme (2002) have also shown that the area and $\mathrm{pH}$ influence species richness in natural lakes of various geographic regions of the world.

The relative abundance is more for some species such as Mystus armatus, Mystus vittatus, Heteropneustes fossilis, Neotropius atherinoides and Mystus gulio. Whereas the relative abundance is less for species such as Mystus seengtee, Mystus keletius and Ompok bimaculatus.

The threats on few catfish species in the study region are mainly due to habitat destruction. Raj (2002) had also observed similar types of threats for the catfish, Mystus montanus.

\section{REFERENCES}

Amarasinghe, U.S. \& R.L. Welcomme (2002). An analysis of fish species richness in natural lakes. Environmental Biology of Fishes 65: 327-339.

Angermeier, P.L. \& I.J. Schlosser (1989). Species-Area relationships for stream fishes. Ecology 70(5): 1450-1462.

Bhat, A. (2004). Patterns in the distribution of freshwater fishes in rivers of Central Western Ghats, India and their associations with environmental gradients. Hydrobiologia 529: 83-97.

Daniels, R.J.R. \& B. Rajagopal (2004). Fishes of Chembarampakkam Lake - a wetland in the outskirts of Chennai. Zoos' Print Journal 19(5): 1481-1483.

Devi, K.R., T.J. Indra, M.B. Raghunathan \& M.M Bai (1998). On a collection of fish fauna from Chennai, Chengleput and Thiruvallur districts of Tamil Nadu. Records of the Zoological Survey of India 97(4): 151-166.

Indra, T.J. (1992). Report on the ichthyofauna of Kanyakumari District, Tamil Nadu. Records of the Zoological Survey of India 92(1-4): 177-192.

Jayaram, K.C. (1999). The Fresh Water Fishes of the Indian Region. Narendra Publishing House, Delhi, 551pp.

Jayaram, K.C. (2006). Catfishes of India. Nerandra Publishing House, 383pp. Johal, M.S., K.K. Tandon, Y.K. Rawal, A.K. Tyor, H.S. Banyal \& H.S. Rumana (2001). Species richness of fish in relation to environmental factors. Current Science 80(4): 499-501.

Kumar, A.C.R., N.K. Ramachandran \& A. Asthana (1995). Composition, abundance and distribution of fish in Banganga-Gambhir river system and source of fish to the Keoladeo National Park, Bharatpur. Journal of the Bombay Natural History Society 92: 30-39.

Kumar, A.C.R., K.R. Devi, K.R. Thomas \& C.R. Biju (1999). Fish fauna, abundance and distribution in Chalakudy River system, Kerala. Journal of the Bombay Natural History Society 96(2): 244-254.

Kumar, C.R.A. \& D.D. Mittal (1993). Habitat preference of fishes in wetlands in relation to aquatic vegetation and water chemistry. Journal of the Bombay Natural History Society 90: 181-191.

Ng, H.H. \& M. Kottelat (2008). The identity of Clarias batrachus (Linneaues, 1758), with the designation of a neotype (Teleostei: Clariidae). Zoological Journal of Linnean Society 153: 725-732; http://dx.doi.org/10.1111/ j.1096-3642.2008.00391.x

Raghunathan, M.B. (1978). Studies on seasonal tanks in Tamilnadu 1. Chembarambakkam Tank. Indian Journal of Zootomy XIX (2): 81-85.

Raj, A.J.A. (2002). Conservation of threatened fish species by induced breeding techniques. PhD Thesis. CARE, St. Xavier's College, Tirunelveli, India.

Raj, S.B. (1916). Notes on the fresh water fish of Madras. Records of the Indian Museum XII(IV): 249-294.

Singh, J.P. (1976). Fishes of Kanyakumari - A Handbook on the Study of Fishes. Sharon Press, Karingal, Kanyakumari District, Tamil Nadu, 124pp.

Subramanyam, K. (1961). Aquatic Angiosperms. Botanical Survey of India, Calcutta, 190pp.

Talwar, P.K. \& A.G. Jhingran (1991). Inland Fishes of India and Adjacent Countries - Volume II. Oxford \& IBH Publishing Co. Pvt. Ltd, New Delhi, $525 \mathrm{pp}$.

Venkateswarlu, T., K.V.R. Rao \& T.S.N. Murthy (1975). A list of fishes, amphibians and reptiles of Madras and its vicinity. Indian Journal of Zootomy 16(2): 149-169.

Winemiller, K.O. \& L.C.K. Winemiller (1996). Comparative ecology of catfishes of the Upper Zambezi River floodplain. Journal of Fish Biology 49: 1043-1061.

Zacharias, V.J., A.K. Bhardwaj \& P.C. Jacob (1996). Fish fauna of Periyar Tiger Reserve. Journal of the Bombay Natural History Society 93: 39-43. 